\title{
O conceito freudiano de pulsão e o estatuto epistemológico da psicanálise: o olhar de Heidegger e de Ricoeur
}

\author{
The freudian concept of the drive and the epistemological status of \\ the psychoanalysis: the point of view of Heidegger and Ricoeur
}

\section{Caroline Vasconcelos Ribeiro*}

\begin{abstract}
Resumo: Com esse artigo pretendemos examinar duas posições distintas em relação ao conceito metapsicológico de pulsão e à identidade epistemológica da psicanálise. Ao investigar as bases ontológicas da metapsicologia, o filósofo Martin Heidegger encaixa a psicanálise freudiana no rol das ciências da natureza. Para Heidegger, ao usar o conceito de pulsão para descrever as nossas urgências e ímpetos, Freud estaria usando um constructo teórico carregado de uma objetividade não-humana. Ricoeur, por sua vez, advoga que o conceito de pulsão teria o poder de sintetizar os elementos de força e de sentido presentes na teoria freudiana. Apesar de funcionar como uma força que faz o aparelho psíquico trabalhar, essa força pulsional nunca seria "nua", desprovida de uma representação psíquica que lhe conferiria sentido. Por isso, o conceito de pulsão afinaria a psicanálise com a hermenêutica. Nosso objetivo consiste em analisar os fundamentos que guiam tais posições.
\end{abstract}

Palavras-chave: Ciência Natural; Hermenêutica; Pulsão

\begin{abstract}
With this article we intend to examine two distinct positions related to the metapsychological concept of the drive and the epistemological identity of the psychoanalysis. By investigating the ontological basis of metapsychology, the philosopher Martin Heidegger puts the Freudian psychoanalysis into the list of natural sciences. For Heidegger, by using the concept of the drive for describing our urges and impetus, Freud is using a theoretical construct loaded with a non-human objectivity. Ricoeur, on the other hand, advocates that the concept of the drive would have the power of synthesizing the elements of force and sense in the Freudian theory. Apart from functioning as a force, which makes the psychic apparatus work, this driving force would never be "naked", free from a psychic representation conferring it a sense. Therefore, the concept of drive would harmonize the psychoanalysis with hermeneutic. Our objective consists of analyzing the fundaments, which guide such positions.
\end{abstract}

Keywords: Natural Science; Hermeneutic; Drive

Professora Titular de Filosofia na Universidade Estadual do Sudoeste da Bahia, Candeias, BA. E-mail: carolinevasconcelos@hotmail.com ORCID: https://orcid.org/0000-0001-7866-5473 


\section{O conceito fronteiriço de pulsão}

Com esse artigo almejamos examinar duas posições distintas em relação ao conceito metapsicológico de pulsão e à identidade epistêmica da psicanálise. Ao investigar as bases ontológicas do saber psicanalítico, o filósofo Martin Heidegger aloca o legado freudiano no rol das ciências da natureza e aborda a sua metapsicologia como uma teoria enraizada no solo epistemológico do projeto neokantiano para as ciências naturais. Para Heidegger, o conceito de pulsão padece de uma objetividade não-humana e funciona como uma ferramenta teórica que consolida a afinidade freudiana com uma semântica fisicalista e com o modo de proceder científico-natural. Ricoeur, por sua vez, advoga que o conceito de pulsão teria o poder de sintetizar os elementos de força e de sentido presentes na teoria freudiana. Apesar de funcionar como uma força que faz o aparelho psíquico trabalhar, essa força pulsional nunca seria "nua”, desprovida de uma representação psíquica que lhe conferiria sentido. Por isso, o conceito em comento seria responsável por instituir um elo entre força e sentido, o que colocaria o elemento hermenêutico em destaque na psicanálise. Ainda que o conceito de pulsão trouxesse consigo traços do naturalismo presente no início do itinerário da pesquisa freudiana, a forma como essa força se faria presente no psiquismo seria sempre carregada de representação. Por isso, Ricoeur elege este conceito como aquele que livraria a psicanálise das fortes amarras naturalistas. Posto que estes autores apresentam posições contrastantes em relação a este conceito cardeal da psicanálise e à sua própria identidade epistemológica, nos dispomos examinar os fundamentos de cada posição. Antes de adentramos nessa discussão apresentaremos, ainda que em traços largos, a visão freudiana sobre o conceito de pulsão.

Na conferência Ansiedade e Vida pulsional, Freud refere-se à sua teoria das pulsões como uma mitologia. A conferência - escrita para ouvintes imaginários por conta de sua impossibilidade em falar em público, devido a uma cirurgia - pretende relatar novidades a respeito de sua concepção de ansiedade e das pulsões básicas que regem a vida psíquica. Depois de explicar sobre o mecanismo da ansiedade nas neuroses, o autor avisa aos seus “ouvintes” que adentrará na seara da teoria das pulsões, em relação a qual a psicanálise não tem feito avanços. Freud, então, afirma:

A teoria das pulsões é, por assim dizer, a nossa mitologia. As pulsões são entidades míticas, magníficas em sua imprecisão. Em nosso trabalho não podemos desprezá-las, nem por um só momento, de vez que nunca estamos seguros de os estarmos vendo claramente ${ }^{1}$.

Nessa citação, Freud assume uma imprecisão em relação às pulsões e coloca-se na condição de um pesquisador que não pode assegurar uma palavra final sobre o assunto. Coloca-se não como um cientista seguro dos frutos de seu labor, mas como um investigador

${ }^{1}$ FREUD, Ansiedade e Vida pulsional, 98 
que tem pouca clareza sobre o que postula. Ora, essa postura não parece ser a de um resoluto cientista da natureza. Será que um decidido cientista natural seria capaz de se referir a um aspecto de sua teoria como uma mitologia? Uma investigação que tem em mãos um conceito obscuro como o de pulsão não revela uma posição distinta daquela que é cativa a cientistas naturais que lidam com conceitos inquebrantáveis? A referência ao campo mitológico parece ser antípoda a uma caracterização da psicanálise como uma ciência da natureza, uma vez que os termos "mitologia" e "ciência natural" parecem não obter guarida num mesmo terreno epistemológico. Sendo assim, cumpre indagar: o conceito de pulsão estaria a serviço da classificação da psicanálise como uma ciência da natureza? A resposta de Ricoeur a essa pergunta seria: não! A resposta de Heidegger seria: sim! Para contrastarmos essas posições, temos que realizar a tarefa prévia de examinar a natureza deste conceito. Faremos isso abaixo.

Ao fazer um apanhado sobre o lugar do termo $T r i e b^{2}$ no itinerário da pesquisa freudiana, Garcia-Roza nos informa que este termo - corrente na língua germânica aparece em textos de Freud já nos anos 90 do século XIX. N'O projeto (1895), n' $A$ interpretação dos sonhos (1900) e na obra Três ensaios sobre a sexualidade (1905) Freud, diz o autor, faz usos tímidos do termo, dotando-lhe de contornos pouco definidos. Esse tratamento não conceitual destinado ao Trieb desaparecerá no clássico escrito intitulado $A$ pulsão e seus destinos, no qual Freud considerará a pulsão “(...) como um dos conceitos fundamentais (Grundbegriffe) da psicanálise”3.

Freud empenha-se em distinguir dois tipos de excitações que podem agir sobre o psiquismo. Uma delas consiste num estímulo (Reiz) que tem fonte externa e, por isso, pode atuar momentaneamente sobre o psíquico, sendo passível de evitação ou fuga; por exemplo, uma fuga motora resultante da percepção algo que incomoda (luz forte, calor ou frio excessivo). A outra fonte de excitação é interna e atua de modo incessante, não sendo possível fugir, posto que não vem de fora, mas de dentro ${ }^{4}$. As pulsões têm essa natureza, são forças constantes, ou seja, forças motrizes atuantes no interior do aparelho psíquico. Para Freud, a pulsão é:

(...) um conceito fronteiriço entre o anímico (Seelischen) e o somático, como representante psíquico [psychischer Repräsentant] dos estímulos oriundos

\footnotetext{
${ }^{2}$ Segundo Laplanche e Pontalis, a palavra instinto (Instinkt, em alemão) é usada por Freud para caracterizar o comportamento animal fixado hereditariamente. Como o termo Trieb - de raiz germânica e não latina como Instinkt - tem o sentido de impelir, os autores, para evitar qualquer espécie de biologismo verteram Trieb para pulsion (pulsão). O intuito consiste em evidenciar o sentido de impulsão. cf.: LAPLANCHE e PONTALIS, Vocabulário da Psicanálise, .394. Como estamos usando a versão bilingue de Pedro Tavares, nos serviremos, neste texto, do vocábulo pulsão para a palavra alemã Trieb.

${ }^{3}$ GARCIA-ROZA, Introdução à metapsicologia freudiana, v.3, 80

${ }^{4}$ FREUD, A pulsão e seus destinos, 19
} 
do interior do corpo que alcançam a alma, como uma medida da exigência de trabalho imposta ao anímico em decorrência de sua relação com o corporal ${ }^{5}$.

Ao falar de uma exigência de trabalho feita ao psiquismo, Freud nos remete a uma pressão (Drang) constitutiva da pulsão. Essa pressão refere-se ao seu fator motor, a uma "quantidade de força” que exige que a pulsão atinja a sua meta (Ziel), a saber, a satisfação. A possibilidade de satisfação é veiculada pela eliminação do estado de estimulação na fonte da pulsão. Ao visar abolir este estado de estimulação, a pulsão precisa de um objeto (Objekt) para atingir sua meta. Esse objeto, por usa vez, não é fixo e varia de acordo com a história do indivíduo. Apesar de inespecífico, o objeto não é necessariamente algo estranho e pode, inclusive “(...) ser uma parte do próprio corpo" ${ }^{6}$ da pessoa.

Os objetos de investimento pulsional variam ao longo da existência da pessoa, em outros termos, variam de acordo com os destinos das pulsões ao longo da vida. Garcia-Roza, ao esclarecer o sentido que Freud empresta ao termo "objeto da pulsão", destaca que a língua alemã tem duas palavras para objeto: Gegenstand e Objekt. A primeira se refere ao “(...) objeto do mundo, o que está aí, o que se oferece à percepção”. Já o termo Objekt “(...) designa uma representação complexa, síntese de sensações elementares provenientes das coisas do mundo"'. Freud nos fala em Objekt da pulsão. Sendo assim, ainda segundo Garcia-Roza, o objeto da pulsão não é uma coisa do mundo meramente captada pela percepção externa, mas uma síntese de representações, denominada representação-objeto (Objektvorstellung) ${ }^{8}$. Nessa perspectiva, quando Freud fala em investimento pulsional ou investimento de objeto, "não quer significar que a pulsão investe objetos externos (Gegenstände), mas sim que ela investe em representações-objeto" .

Cumpre indicar que, além dos três elementos mencionados acima como constitutivos da pulsão - pressão, finalidade e objeto -, Freud sugere um quarto: a fonte (Quelle). Quanto à esta fonte, o pai da psicanálise define como o processo somático que ocorre num órgão ou em parte do corpo, cujo estímulo é representado na vida anímica pela pulsão. Confessa não saber, ao certo, se esse processo somático é somente de natureza química ou se poderia corresponder à liberação de forças mecânicas e, nesse sentido, pondera que o estudo sobre a diversidade das fontes pulsionais extrapola o âmbito de sua psicologia. Além disso, admite que o conhecimento exato das fontes somáticas da pulsão não é absolutamente “(...) necessário para a investigação psicológica”"10.

\footnotetext{
${ }^{5}$ FREUD, A pulsão e seus destinos, 25

${ }^{6}$ FREUD, A pulsão e seus destinos, 27

7 GARCIA-ROZA, Introdução à metapsicologia freudiana, v.3, 93. Conferir, também, as notas 18 e 19 da tradução de Pedro Tavares: FREUD, A pulsão e seus destinos, 67

${ }^{8}$ GARCIA-ROZA, Introdução à metapsicologia freudiana, v.3, 95

${ }^{9}$ GARCIA-ROZA, Introdução à metapsicologia freudiana, v.3, .93

${ }^{10}$ FREUD, A pulsão e seus destinos, 27
} 
A discussão sobre a fonte da pulsão nos impõe a investigação sobre a forma como a pulsão se exprime na vida anímica. Hanns alega que se Trieb tem uma fonte somática, ou seja, brota no corpo, sua forma de apresentação, contudo, é psíquica ${ }^{11}$. Como destaca Garcia-Roza, Freud afirma que a pulsão é considerada como um estímulo para o psíquico e não estímulo psíquico. Qual seria a diferença? A diferença é que se entendemos a pulsão como um estímulo psíquico simplesmente ignoramos a sua fonte somática, mas se, em contrapartida, a compreendemos como um estímulo para o psíquico resguardamos a natureza de sua fonte, ao passo em que nos deparamos com a questão sobre sua forma de se fazer presente na vida psíquica. A pergunta que se impõe é: como o estímulo pulsional que parte de uma fonte corporal - alcança o psiquismo?

Como vimos, para Freud a pulsão é um conceito situado na fronteira entre o anímico e o somático, sendo assim, ela é uma Repräsentanz psíquica das excitações que se originam dentro do corpo e alcançam o psíquico. Como adverte Garcia-Roza, Freud usa, dentre outros, os termos Repräsentanz, Triebrepräsentanz, psychische Repräsentanz, psychischer Repräsentant para se referir à pulsão ${ }^{12}$. Ricoeur afirma que Freud forja uma expressão excelente que é: Repräsentanz. Como no escopo deste artigo não cabe uma discussão sobre a forma como comentadores traduzem estes diversos termos, vamos nos concentrar no sentido deste termo que o filósofo francês destaca. Ricoeur traduz Repräsentanz como presentação. Para o comentador francês, Freud usa a expressão psychische Repräsentanz para se referir à presentação psíquica da pulsão e não à sua representação (Vorstellung). A presentação psíquica funciona como algo psíquico que "vale pela" pulsão. Consiste no modo como a energia da pulsão, que tem fonte somática, se exprime, se presenta no psiquismo. Ricoeur afirma:

Há algo de psíquico que 'presenta' a pulsão (present la pulsion) enquanto energia, pois o que chamamos representação (Vorstellung), isto é, a ideia de algo, já é uma forma derivada deste índice que, antes de representar algo mundo, corpo próprio, irreal - anuncia a pulsão como tal, presenta-a pura e simplesmente ${ }^{13}$.

Garcia-Roza entende o termo Repräsentanz como representância ou agência representante, indicando o modo como a pulsão se apresenta no psiquismo, como “(...) uma forma de presentificação da pulsão no psiquismo, algo de caráter puramente intensivo e não ideativo como na Vorstellung" ${ }^{14}$. Laplanche e Pontalis, em contrapartida, vertem psychische Repräsentanz ou psychischer Repräsentant para représentant psychique

\footnotetext{
${ }^{11}$ HANNS, Dicionário comentado do alemão de Freud, 351

${ }^{12}$ Garcia-Roza faz uma tabela com possibilidades de tradução destes termos, alguns com diferenças sutis. Cf.:GARCIA-ROZA, Introdução à metapsicologia freudiana, v.3,249.

${ }^{13}$ RICOEUR, Da interpretação: ensaio sobre Freud, 117

${ }^{14}$ GARCIA-ROZA, Introdução à metapsicologia freudiana, v.3, 265.
} 
(representante psíquico) e assinalam que o termo é entendido como a expressão psíquica das excitações endossomáticas ${ }^{15}$. Apesar da falta de consenso nas traduções, ressaltamos que os estudiosos diferem nas palavras, mas não no sentido. Do que foi exposto se pode inferir que a pulsão não é puramente psíquica, nem puramente corporal, mas uma energia que tem fonte no corpo e se faz presente no psiquismo, ou seja, é algo que vem de fora do aparelho psíquico e se presenta como uma exigência de trabalho. Nesse sentido, GarciaRoza afirma que a pulsão é:

Algo, portanto, que do exterior faz uma exigência de trabalho ao aparato [psíquico]. E quando a consideramos do ponto de vista anímico, o que está sendo enfatizado é o modo dela se fazer presente no psiquismo, isto é, enquanto Triebrepräsentanz. O conceito de pulsão aponta, portanto, para esse duplo registro - somático e o anímico - o que faz com que Freud afirme seu estatuto de conceito fronteiriço ${ }^{16}$.

Enquanto conceito fronteiriço, a pulsão articula a fonte somática da excitação com o aparelho psíquico, para tanto, ela precisa se expressar psiquicamente. A carga de excitação é gerada em sua fonte somática, em outros termos, a força constante promotora de tensões internas tem seu nascedouro no corpo e se impõe como exigência de trabalho ao psiquismo. Tal forma de imposição, ou seja, a expressão desta carga no aparelho psíquico ocorre via presentação (Repräsentanz) da pulsão. Como atesta Laplanche e Pontalis, a situação de fronteira faz com que Freud postule o Repräsentanz da pulsão enquanto uma espécie de "delegação" do somático no psíquico" ${ }^{17}$.

Assoun nos indica que, no aparato psíquico, a pulsão se exprime, se presenta, através de dois representantes, quais sejam: Vorstellung (representação propriamente dita) e Affekt $(\text { afeto })^{18}$. Em outras palavras: a presentação da pulsão (Triebrepräsentanz) no psiquismo se veicula através da representação e do afeto. O termo Vorstellung, apesar de não poder ser considerado um conceito uniforme e consensual, é usado por Freud - especialmente nos textos de divulgação dirigidos a um público de não especialistas - no sentido de ideia, imagem, pensamento ${ }^{19}$. No Dicionário comentado do alemão de Freud, Hanns elenca 16 passagens da obra freudiana e nos indica diferentes modos de Vorstellung aparecer: ora como ideia, ora como conceito, ora como apresentação ou representação mental-imagética de uma palavra, ora como concepção. Dada essa polissemia, cumpre-nos indicar que, em

\footnotetext{
${ }^{15}$ LAPLANCHE e PONTALIS, Vocabulário da Psicanálise, 454

${ }^{16}$ GARCIA-ROZA, Introdução à metapsicologia freudiana, v.3, 255.

${ }^{17}$ Cf.: LAPLANCHE e PONTALIS, Vocabulário da Psicanálise, 454

${ }^{18}$ ASSOUN, Metapsicologia freudiana: uma introdução, p.84

${ }^{19}$ Cf.: HANNS, Dicionário comentado do alemão de Freud,397
} 
Freud, o termo Vorstellung refere-se à representação de um objeto/coisa ou de uma palavra e indica a parte ideativa ou imagética da presentação da pulsão no aparelho psíquico ${ }^{20}$.

Quanto ao outro delegado da pulsão, o afeto, convém lembrar que corresponde a processos de descargas, cuja manifestação é percebida pelo psiquismo como sensações ${ }^{21}$. O afeto é o fator quantitativo do impulso pulsional, por isso Freud nos fala de quantum de afeto. Enquanto o Affekt corresponde à parte intensiva, relativa à intensidade da presentação da pulsão, a Vorstellung, diz Garcia-Roza, é a parte da significação ${ }^{22}$. Nesse sentido, vale ressaltar que:

Uma pulsão nunca pode tornar-se objeto da consciência - só a ideia (Vorstellung) que a representa (repräsentiert) pode. Além disso, mesmo no inconsciente uma pulsão não pode ser representada (repräsentiert) de outra forma a não ser por uma ideia (Vorstellung). Se a pulsão não se prendeu a uma ideia ou não se manifestou como um estado afetivo, nada poderemos conhecer sobre ela ${ }^{23}$.

O que sabemos da pulsão se restringe ao modo como ela se presenta. E ela se faz psíquica mediante representação e afeto. Apesar de o afeto se ligar originalmente a uma representação, essa ligação, esclarece Garcia-Roza não é fixa, pois o afeto pode se deslocar “de uma representação para outra" ${ }^{24}$. Se uma determinada representação estiver ligada a uma energia pulsional de ação patogênica e insuportável, a dupla (afeto e representação) sofrerá a força da repressão (Verdrängung). A Vorstellung e o Affekt, enquanto dupla de delegados que presentam a pulsão no psiquismo, podem se divorciar em consequência da ação da repressão ${ }^{25}$. Mas os destinos de cada componente dessa dupla são distintos.

Segundo Freud, o conteúdo ideativo conflitivo pode ser interditado da consciência caso seja previamente consciente, ou ser afastado da consciência, caso esteja em vias de tornar-se consciente. Nas duas situações, diz o pai da psicanálise, a diferença não é fundamental, pois corresponde à diferença entre ordenar que um hóspede indesejado saia

${ }^{20}$ Cf.: HANNS, Dicionário comentado do alemão de Freud, 391-396. A distinção entre representação de palavra (Wortvorstellung) e representação de coisa (Sachvorstellung) se relaciona com essa discussão, mas, levantá-la aqui, nos distanciaria do objetivo do trabalho. Remeto o leitor a: FREUD, O inconsciente.

${ }^{21}$ FREUD, O inconsciente, 183

${ }^{22}$ GARCIA-ROZA, Introdução à metapsicologia freudiana, v.3, 266,

${ }^{23}$ FREUD, $O$ inconsciente, 182

${ }^{24}$ GARCIA-ROZA, Introdução à metapsicologia freudiana, v.3, 12

${ }^{25}$ A repressão é apenas um entre os destinos da pulsão. Os outros são: reversão ao seu oposto; retorno em direção ao próprio self do indivíduo e sublimação. Em função do escopo desse trabalho, nos ateremos apenas à repressão. A tradução de Verdrängung por repressão não é um processo que goza de consenso entre os tradutores. Alguns vertem para recalcamento. Aqui optamos seguir a linha de tradução de Loparic, que advoga pelo termo repressão devido ao elo semântico entre Verdrängung e Drang (pressão). cf.: LOPARIC, Além do Inconsciente - sobre a desconstrução heideggeriana da psicanálise. 
da sala de visitas ou evitar que ele cruze a soleira da porta. Em ambas as circunstâncias, a presença do que incomoda é removida. Já o elemento intensivo e não ideativo da pulsão, o quantum de afeto, segue outro destino. Freud afirma que esse fator quantitativo da presentação pulsional possui três vicissitudes possíveis, quais sejam: 1- o quantum de afeto pode ser suprimido sem deixar vestígios; 2- pode ser "qualitativamente colorido"; 3- ou transformado em angústia ${ }^{26}$. Se o controle em relação ao elemento ideativo da pulsão pode ser mais efetivo, a ação movida para impedir a descarga de uma quantidade de afeto capaz de gerar desprazer e tensão no aparelho psíquico é bem mais complexa. Apesar de uma repressão ser exitosa no tocante à Vorstellung, ela pode falhar quanto à descarga de afeto. Nesse sentido, Freud afirma:

Recordamos o fato de que o motivo e o propósito da repressão nada mais eram do que a fuga ao desprazer. Depreende-se disso que a vicissitude da quota de afeto pertencente ao representante é muito mais importante do que a vicissitude da ideia (Vorstellung), sendo esse fato decisivo para nossa avaliação do processo de repressão. Se uma repressão não consegue impedir que surjam sentimentos de desprazer ou de ansiedade, podemos dizer que falhou ainda que possa ter alcançado seu propósito quanto à parcela ideacional ${ }^{27}$.

A discussão sobre o conceito de pulsão envolve muitos aspectos teóricos, pois trata da energia que força o aparelho psíquico a trabalhar, ou seja, trata do que move a vida anímica. Entendemos que, no escopo desse trabalho, não cabe uma discussão maior sobre os diferentes destinos da pulsão e suas consequências clínicas. Nossa intenção inicial consistiu em descrever o conceito, seus componentes, sua natureza. Tal descrição foi necessária porque indicaremos duas posições distintas sobre a pulsão que levarão em consideração alguns destes aspectos. Abordaremos, inicialmente, a posição de Paul Ricoeur.

\section{A pulsão como elo entre força e sentido: o argumento de Ricoeur}

No prefácio da obra Da interpretação: ensaio sobre Freud, Ricoeur esclarece ao leitor a proveniência do livro e o seu propósito. A proveniência diz respeito a três conferências ministradas pelo autor, no outono de 1961, na Universidade de Yale e o propósito da obra consiste numa leitura filosófica sobre Freud e não sobre a psicanálise como um todo, o que implicaria numa discussão com os pós-freudianos. No livro II da obra, intitulado Analítica: leitura de Freud, Ricoeur avisa ao seu leitor que considera o

\footnotetext{
${ }^{26}$ FREUD, Repressão,158

${ }^{27}$ FREUD, Repressão, 158
} 
fundador da psicanálise um "combatente da hermenêutica” que desapropria a consciência e “(...) regula a ascese desse narcisismo que pretende fazer-se tomar pelo verdadeiro cogito"28.

Ao assumir sua posição em relação a Freud, o pensador francês indica que sua abordagem ingressará na psicanálise “(...) por aquilo que ela tem de mais exigente, pela sistemática, que o próprio Freud chamou de sua Metapsicologia” 29 . Guiado pela questão "o que significa interpretar em psicanálise?”, o autor vai defender que Freud alterna entre a explicação econômico-energetista e a exegese de sentido, a hermenêutica. Para Ricoeur, o discurso misto é a razão de ser da psicanálise, o que torna complicada a alcunha de ciência natural para um saber que agrega à perspectiva das forças e energias a interpretação dos sentidos latentes. Além disso, Ricoeur acrescenta que os conteúdos sobre os quais o analista trabalha são representações: seja uma fantasia, uma obra de arte ou uma crença religiosa. Ancorado nesse argumento, o autor em comento, apresenta questões que julga serem incontornáveis, são elas: qual o estatuto da representação relativamente à noção de pulsão? Como interpretar os sentidos diante de uma economia de investimentos e contra investimentos?

A conjugação entre energia e sentido que, à primeira vista parece antinômica, será harmonizada, segundo Ricoeur, com o conceito de pulsão, mais especificamente com a ideia de presentação da pulsão. Sua defesa de Freud como um combatente da hermenêutica passa pela análise desse conceito ${ }^{30}$.

Antes de tematizarmos a maneira como Ricoeur aborda o conceito de pulsão, convém indicarmos a leitura operada por ele em relação ao itinerário da pesquisa freudiana. No capítulo intitulado Uma energética sem hermenêutica, Ricoeur defende que a teoria exposta por Freud n'O projeto de 1985 é de cunho naturalista, visto que representa os processos psíquicos como estados quantitativos, fala de neurônios investidos e se serve de uma terminologia física para falar de um princípio de conservação de energia no psiquismo. Contudo, se n' $O$ projeto o esquema do aparelho era uma representação real, no capítulo VII de $A$ interpretação dos sonhos, o aparelho freudiano “(...) funciona sem referência anatômica, é um aparelho psíquico'31. Uma vez que se constitui como uma representação figurada, o aparelho não pode ser pensado como a máquina que aspira ter representações reais, mas como um modelo, como uma "representação auxiliar", sem pretensões de

\footnotetext{
${ }^{28}$ RICOEUR, Da interpretação: ensaio sobre Freud, 60

${ }^{29}$ RICOEUR, Da interpretação: ensaio sobre Freud, 60

30 Vale lembrar que Ricoeur coloca Freud ao lado de Marx e Nietzsche no grupo dos protagonistas da hermenêutica da suspeita: "O filósofo contemporâneo encontra Freud nas mesmas paragens que Nietzsche e Marx. Todos os três se apresentam diante dele como os protagonistas da suspeita, os perfuradores de máscaras. Nasceu um problema novo: a mentira da consciência, da consciência como mentira. RICOEUR, $O$ conflito das interpretações, 87

${ }^{31}$ RICOEUR, Da interpretação: ensaio sobre Freud, 83
} 
correspondência empírica. Por isso, diz Ricoeur, Freud fala em ideias investidas e não em neurônios investidos. Para o autor, o maquinismo inicial do Projeto cedeu lugar, em $A$ interpretação dos sonhos, para a cifração e decifração. O trabalho concreto de análise onírica subordinou a explicação à interpretação, fazendo prevalecer a linguagem do sentido $^{32}$. No capítulo intitulado Energética e hermenêutica em "A interpretação dos sonhos”, Ricoeur esclarece:

Com $A$ interpretação dos sonhos a explicação sistemática é transferida para o fim de um trabalho efetivo cujas regras mesmas são elaboradas; e ela é expressamente destinada a transcrever graficamente o que se passa no trabalho do sonho, que em si mesmo, só é acessível no e pelo trabalho de interpretação. Não é por acaso que este livro se chama Traumdeutung. A interpretação dos $\operatorname{sonhos}^{33}$.

Os argumentos exibidos acima advogam pela presença de uma hermenêutica mesclada com a energética e anunciam o abandono de uma abordagem concreta do psíquico, afinal, Freud nos fala de um aparelho com lugares psíquicos a construir o material do sonho. Por isso, ao descrever a máquina de sonhar em $A$ interpretação dos sonhos, Freud se serve de analogias com microscópio ou com o utensílio fotográfico para falar do funcionamento do aparelho psíquico. A espacialidade desse aparelho não passa, diz Ricoeur, de uma "representação auxiliar" ${ }^{4}$. Revela-se, assim, na obra sobre os sonhos, uma aptidão freudiana para a figuração. Dizer isso não significa, na perspectiva ricoeuriana, dizer que Freud alcança uma total ruptura em relação ao energetismo característico d'O projeto. O pai da psicanálise estaria ainda a "flutuar entre duas águas”, dado o recurso marcante, na explicação dos sonhos, a mecanismos que ainda remetem ao princípio físico de constância e a regulação energética. Como afirma Monzani, para Ricoeur a obra sobre os sonhos é carregada de um discurso misto, que mescla a linguagem física da tópica e a linguagem do sentido, que provém da interpretação ${ }^{35}$.

Os escritos de metapsicologia representam, para Ricoeur, a maturidade da problemática entre os dois aspectos do discurso psicanalítico. Nesses escritos, Freud teria alcançado o ponto de equilíbrio entre força e sentido. Para provar isso, Ricoeur procede a uma análise do conceito metapsicológico fundamental: pulsão. Para o autor, "há um ponto em que a questão da força e a questão do sentido coincidem. Esse ponto é aquele onde a

\footnotetext{
${ }^{32}$ Trabalhamos a posição de Ricoeur sobre a produção onírica num artigo em que colocamos o contraponto da visão heideggeriana sobre o tema. Cf: ALMEIDA e RIBEIRO, Freud e a teoria da elaboração dos sonhos: investigações à luz da filosofia de Martin Heidegger e de Paul Ricoeur

${ }^{33}$ RICOEUR, Da interpretação: ensaio sobre Freud, 83

${ }^{34}$ RICOEUR, Da interpretação: ensaio sobre Freud, 93

${ }^{35}$ Cf.: MONZANI, Freud: o movimento de um pensamento,87
} 
pulsão se designa a si mesma, torna-se manifesta, dá-se numa 'presentação psíquica', isto é, num algo psíquico que 'vale pela' pulsão" 36 .

Ora, se nada podemos dizer da pulsão em si, devemos concluir que só podemos acessá-la a partir de sua presentação psíquica. Isso significa dizer que da pulsão só lidamos com sua presentação e não com a quantidade de excitação que provém de sua fonte, a saber, o corpo. Ao insistir nesse modo de abordar o conceito de pulsão, Ricoeur nos recorda que Freud privilegia a linguagem compósita e, nesse sentido, assegura que a pulsão é uma exigência de trabalho imposta ao psiquismo em função de sua conexão com o corporal. Indicar a existência dessa exigência de trabalho, dessa pressão (Drang) característica da pulsão, não significa, na ótica de ricoeuriana, sobrepor o ponto de vista econômico ao elemento do sentido, interpretativo. Pois, uma vez que a pulsão se exprime por presentações, todas as formas de pressão incidem somente no destino das presentações psíquicas: seja no destino do afeto (Affekt), seja no destino da representação (Vorstellung). Nesse sentido, o filósofo francês argumenta que é preciso afirmar com radicalidade que o conceito de pulsão “(...) presenta, exprime, o corpo na alma, no plano psíquico (in die Seele)"37. Por conseguinte, tal conceito fundamental retira a ciência freudiana da seara puramente organicista e a qualifica como psico-análise, como uma ciência interpretativa.

No decorrer do capítulo III, intitulado Pulsão e representação nos escritos de metapsicologia, testemunhamos o esforço de Ricoeur em acentuar o elemento hermenêutico da psicanálise, para tanto, o autor nos indica que o destino energético das pulsões aparece na linguagem, ou seja, só aparece enquanto destino de suas expressões psíquicas. Por isso, a distância entre o elemento econômico e a hermenêutica, que parecia insuperável em $A$ interpretação dos sonhos, “(...) parece ter desvanecido nos escritos de Metapsicologia" 38 .

A análise ricoeuriana não padece de pressa e, apesar de reforçar o elemento de sentido característico da presentação da pulsão, o autor afirma que tudo iria bem caso fosse possível ignorar a outra categoria da presentação da pulsão: os afetos. Eis a quantidade que nos embaraça desde $O$ projeto, diz Ricoeur ${ }^{39}$. Se Freud nos fala de carga de afeto (Affektbetrag), de carga de energia psíquica, como o outro delegado da pulsão, como seria possível defender que ele elimina ou minimiza a linguagem energética e das forças? Não estaríamos, ainda e sempre, fincados no terreno naturalista, no terreno das quantificações? Então, pergunta Ricoeur: a quota afetiva da pulsão não remeteria a psicanálise à física? Sua resposta é categórica: "de forma alguma” ${ }^{40}$. Ao explicar tal posição, enfatiza que "o destino

\footnotetext{
${ }^{36}$ RICOEUR, Da interpretação: ensaio sobre Freud, 117

${ }^{37}$ RICOEUR, Da interpretação: ensaio sobre Freud, 118

${ }^{38}$ RICOEUR, Da interpretação: ensaio sobre Freud, 119

${ }^{39}$ RICOEUR, Da interpretação: ensaio sobre Freud, 120

${ }^{40}$ RICOEUR, Da interpretação: ensaio sobre Freud, 120.
} 
dissociado do afeto não poderá nos fazer esquecer que o afeto permanece afeto de uma representação" ${ }^{41}$. Até mesmo a angústia, enquanto afeto puro, cuja descarga anárquica não se liga a um objeto determinado, é concebida como “(...) um afeto à espera de uma representação substitutiva a que poderá ligar sua sorte" ${ }^{42}$.

No livro Hermenêutica e psicanálise na obra de Paul Ricoeur, Franco adverte o quão cara é para o filósofo francês a distinção entre presentação (Repräsentanz) e representação (Vorstellung) das pulsões. Segundo Franco, Ricoeur de fato “(...) se sente satisfeito de encontrar na noção de pulsão, mais precisamente na noção de presentação da pulsão, um encontro íntimo, para dentro do próprio conceito, entre força (energia) e sentido (presentação psíquica)" ${ }^{43}$.

Certo de que todo afeto dissociado é um afeto “à procura” de um suporte representativo que lhe abrirá caminho à consciência, Ricoeur defende que nenhuma tentativa de pensar a sobreposição do aspecto econômico em relação ao elemento do sentido (interpretativo) é sustentável, uma vez que é inapagável o fato de que faz parte da constituição do afeto ser carga de uma representação. Em prol da caracterização da psicanálise como um pensamento em que domina o elemento hermenêutico, assevera que:

A psicanálise jamais põe em confronto forças nuas, mas sempre forças em busca de um sentido. É esse elo da força com o sentido que faz da própria pulsão uma realidade psíquica ou, mais exatamente, o conceito limite, na fronteira do orgânico com o psíquico. Portanto, podemos distender tanto quanto possível o elo entre hermenêutica e econômica - a teoria do afeto marca o ponto extremo desta distensão na metapsicologia freudiana -, esse elo não poderá ser rompido, sob pena de a própria econômica deixar de pertencer a uma psico-análise ${ }^{44}$.

A crença de que a linguagem dos sentidos minimiza as explicações econômicas faz Ricoeur advogar pelo poder de síntese do conceito de pulsão, elegendo-o como aquele que livraria a psicanálise das fortes amarras naturalistas presentes n' $O$ projeto e remanescentes em $A$ interpretação dos sonhos. Com o conceito de pulsão, o elemento econômico não apagaria a característica da constituição do afeto, qual seja, a de ser carga da representação. Como comenta Monzani, para Ricoeur, “(...) a força, o energético, o

\footnotetext{
${ }^{41}$ RICOEUR, Da interpretação: ensaio sobre Freud, 120 (parole). RICOEUR, O conflito das interpretações, 91

${ }^{43}$ FRANCO, Hermenêutica e psicanálise na obra de Paul Ricoeur, 123

${ }^{44}$ RICOEUR, Da interpretação: ensaio sobre Freud, 124
}

${ }^{42}$ RICOEUR, Da interpretação: ensaio sobre Freud, 122. Em Conflito das interpretações, Ricoeur afirma: “É porque renuncia atingir o ser das pulsões, e porque permanece nos limites das investigações conscientes e inconscientes da pulsão, que a investigação freudiana não se perde num realismo incognoscível. Seu inconsciente, diferentemente do dos românticos, é essencialmente cognoscível, porque os "representantes representativos' da pulsão ainda são da ordem do significado e homogêneo, de direito, ao império da fala 
quantitativo se transformarão e se exprimirão através dessa presentação e nesse momento ocorrerá a metamorfose produzindo um efeito original de sentido" ${ }^{45}$.

A pulsão é, para Ricoeur, o mais importante postulado da metapsicologia freudiana e é justamente pelas características aqui apresentadas - relativas à sua presentação psíquica e ao fato de o afeto sempre se acoplar a uma representação - que o autor diz ser compreensível quando Freud qualifica a teoria das pulsões como sua mitologia. O argumento de Ricoeur segue a direção de indicar o mitológico como algo incompatível com o cientificismo natural. Nesse sentido, assevera que “(...) não resta dúvida de que a psicanálise seja uma hermenêutica: não é por acaso, mas por destino que ela visa a dar uma interpretação da cultura em seu conjunto" ${ }^{46}$. Para o autor, a psicanálise é, "de ponta a ponta”, interpretação.

\section{Pulsão e a objetividade não-humana: o argumento de Heidegger}

Para Heidegger, a função metodológica do conceito de pulsão segue parâmetros procedimentais das ciências naturais e está a serviço de explicações objetificantes acerca do existir humano. Vejamos o que afirma nos Seminários de Zollikon:

Para se reconduzir o querer, o desejar, tender e ansiar a 'pulsões' então devese sempre, em primeiro lugar, contra-argumentar: será que em toda construção freudiana da teoria da libido o homem está mesmo ai? Pulsão é sempre uma tentativa de explicação, mas é preciso observar, em primeiro lugar, o que é mesmo o fenômeno que se quer explicar e como ele é. Tenta-se sempre explicar por pulsões algo que, pra começar, nem se viu. As tentativas de explicação dos fenômenos humanos a partir de pulsões têm o caráter metódico de uma ciência, cuja matéria não é o homem, mas sim a mecânica. Por isso, é fundamentalmente discutível se um método tão determinado por uma objetividade não-humana pode mesmo ser apropriado para afirmar o que quer que seja sobre o homem qua homem ${ }^{47}$.

A partir da passagem acima podemos perceber que Heidegger questiona o alcance de uma abordagem que postula a presença de um jogo de forças no interior de um aparelho psíquico. É possível notar que o filosofo põe sob suspeita a possibilidade de se alcançar o homem enquanto homem a partir de uma categoria cujo perfil explicativo vale para coisas distintas do ser humano, ou seja, vale para entes físicos, naturais. A objetividade nãohumana presente num constructo inspirado na semântica e na teorização da física, faculta a

\footnotetext{
${ }^{45}$ MONZANI, Freud: o movimento de um pensamento, 89

${ }^{46}$ RICOEUR, Da interpretação: ensaio sobre Freud, 67

${ }^{47}$ HEIDEGGER, Seminários de Zollikon, 192.
} 
Heidegger questionar se o conceito de pulsão é apropriado para pensar as urgências e anseios humanos. Em função disso, o filósofo lança a dúvida se o homem está mesmo presente na teoria freudiana da libido.

Para esclarecer a abordagem heideggeriana do conceito de pulsão devemos, de antemão, investigar a posição de Heidegger em relação à parte teórica da psicanálise na qual este se insere. Em outros termos: convém saber o que o filósofo de Ser e tempo pensa sobre a metapsicologia freudiana. Nos Seminários de Zollikon, Heidegger destaca a filosofia de inspiração kantiana e o modelo científico-natural de pesquisa como elementos constitutivos da seara epistêmica sobre a qual se ergueu e consolidou a metapsicologia de Freud. Para o pensador alemão: "a metapsicologia de Freud é a transferência da filosofia neokantiana para o homem. De um lado ele tem as ciências naturais e de outro a teoria kantiana da objetividade" ${ }^{48}$.

A tarefa que se impõe consiste em indicar de que modo a filosofia de Kant influencia a identidade epistêmica da psicanálise e como tal identidade se ancora em procedimentos cativos às ciências da natureza. Para tanto, recorreremos a textos de pesquisadores que se imbuíram em destrinchar e fundamentar a mencionada posição de Heidegger em relação à metapsicologia. Dentre eles, destacamos Leopoldo Fulgencio e Zeljko Loparic, cujas linhas de pesquisa caracterizam-se pelo estabelecimento de uma apropriação filosófica da psicanálise de Freud. Os mencionados pesquisadores apontam, em diferentes obras, que a função metodológica dos conceitos metapsicológicos cumpre a exigência do programa kantiano de pesquisa nas ciências naturais e afina-se com a "plataforma epistemológica" instituída pelo físico vienense Ernst Mach. Abordaremos isso a seguir.

Loparic destaca a influência do neokantiano Hans Vaihinger e de sua teoria do como se no capital epistemológico freudiano. Tal teoria autoriza o pesquisador a fazer comparações e analogias para descrever um objeto que não é passível de observação direta. Freud se serve dessa perspectiva de análise para versar sobre o psiquismo humano como um aparelho, afinal, não postula a presença de uma máquina no homem, mas um psiquismo que funciona como se fosse uma ${ }^{49}$. No texto intitulado $A$ semântica transcendental de Kant, Loparic nos indica que o filósofo de Königsberg defendeu a presença de uma metafísica da natureza por trás de toda ciência natural ${ }^{50}$.

Kant entende que o caráter metafísico subjacente a uma ciência da natureza está no estabelecimento de princípios, isto é, de leis que não são empíricas, que não se dão na intuição a priori, mas regulam o uso do entendimento, determinando sua extensão ${ }^{51}$. Por

\footnotetext{
${ }^{48}$ HEIDEGGER, Seminários de Zollikon, 222

${ }^{49}$ LOPARIC, A máquina no Homem, 245

${ }^{50}$ LOPARIC, A semântica transcendental de Kant,30

${ }^{51}$ Cf.: KANT, Princípios metafísicos da ciência da natureza. Trabalhamos com mais demora essa influência de Kant sobre Freud em: RIBEIRO, Freud se encaixaria no rol dos operários (Handwerker) das ciências
} 
não possuírem base na experiência, esses princípios e leis fornecidos pela razão são conceitos puros, são ideias. Tais ideias, apesar de não serem verificáveis, funcionam como ficções capazes de organizar o uso sistemático do entendimento no campo da experiência ${ }^{52}$. Dada a ausência de possibilidade de verificação, tais ideias ou princípios puros equivalem a princípios metafísicos que guiam a pesquisa empírica. Para o referido filósofo:

A ciência da natureza propriamente assim chamada pressupõe uma metafísica da natureza; com efeito, leis, isto é, princípios da necessidade do que é inerente à existência de uma coisa, referem-se a um conceito que não se pode construir, porque a existência não pode representar-se em nenhuma intuição a priori. Por conseguinte, a genuína ciência natural pressupõe uma metafísica da natureza. Esta deve, pois, conter sempre puros princípios, que não são empíricos (é por isso que leva o nome de metafísica ${ }^{53}$.

Apesar de caber a uma ciência da natureza prover certezas racionais e objetivas, ela pode se amparar em princípios que, apesar de não apresentarem validade objetiva, podem ser frutíferos para elaborar leis capazes de orientar o conhecimento de objetos observáveis. Isso implica dizer que, no programa kantiano de pesquisa científico-natural, o uso de conceitos a priori não é algo abjeto a ser evitado a qualquer custo e sim algo que faz parte do modo de proceder da ciência. Ao servir-se de conceitos puros que não possuem conteúdos intuitivos relacionados, a razão não estaria portando-se de modo indolente, ao contrário, estaria agindo diligentemente com o fito de descobrir leis que regem os fenômenos, bem como as relações que se estabelecem entre eles.

Os puros princípios, por não possuírem correspondentes empíricos, não podem ser considerados verdadeiros ou falsos, sendo assim, são especulações passíveis de ser descartadas ou substituídas por outras que assumam melhor utilidade, que se mostrem mais eficazes na resolução de problemas. Loparic esclarece que a função dos puros princípios presentes na ciência da natureza é heurística ${ }^{54}$. Tais princípios servem como guias da pesquisa empírica, como instrumentos para a resolução de problemas. O elemento metafísico presente na ciência da natureza não cumpre a função de expor a estrutura $a$ priori da natureza, mas exerce o papel de permitir que o entendimento se sirva de princípios reguladores na resolução de questões atinentes ao domínio da natureza. Os conceitos puros da razão referem-se exclusivamente a entes da razão e não possuem e nem podem possuir realidade empírica ${ }^{55}$. Por isso, tais conceitos são especulativos, são ficções

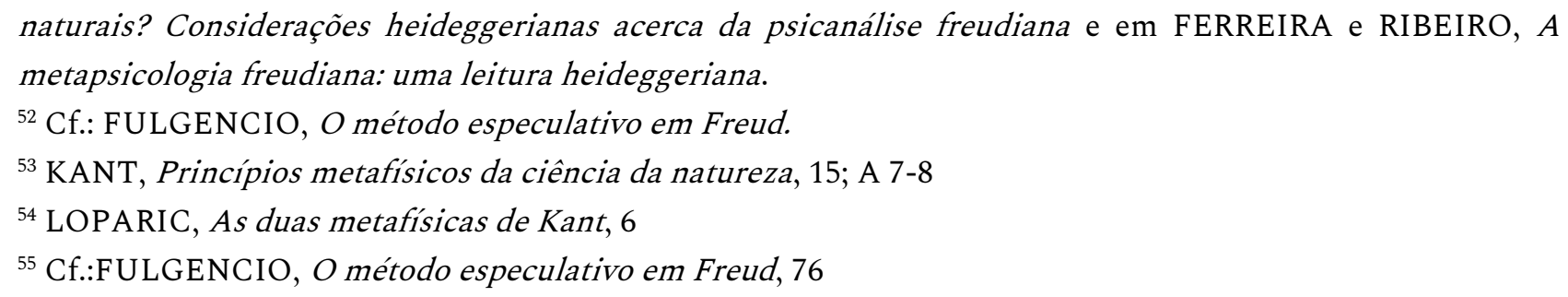


teóricas. Contudo, dizer isso não implica dizer que eles não possam ser ferramentas úteis à formulação de leis aplicáveis ao material empírico, ou seja, ao mundo fenomênico.

Um outro aspecto do programa kantiano para a pesquisa na ciência da natureza, refere-se ao suo de analogias. Fulgencio afirma que, para Kant, tal uso cumpre a função de um tipo de regra para a pesquisa, ou seja, um “(...) esquema que torna possível procurar relações ou termos de uma relação" ${ }^{56}$. Nessa perspectiva, as analogias funcionam como modelos heurísticos de investigação. Uma vez que os conceitos puros não podem ser preenchidos por uma matéria sensível, resta ao pesquisador projetar em tais conceitos, de forma analógica, certas propriedades relativas ao campo empírico. Fulgencio nos ilustra essa operação com o conceito de força na física:

É assim, por exemplo, que o conceito de força, que é apenas uma ideia sem correspondente (referente) empírico, é tomado como se tivesse uma realidade análoga à da pressão que sentimos quando algo toca nosso corpo ou quando colocamos o nosso corpo em movimento ${ }^{57}$.

A ferramenta de interpretação analógica é um recurso imprescindível quando o cientista precisa lançar mão de conceitos que não encontram referência direta no campo empírico. A legitimidade dessa prática é tamanha que o físico vienense Ernst Mach apontou que, desde a antiguidade, a produção do saber se serviu de analogias ${ }^{58}$. Mach elenca exemplos de comparação analógica que foram fundamentais para o desenvolvimento tanto da ciência antiga quanto da moderna. Destaca que Euclides e Platão se serviram de analogias para falar em geometria e que Descartes utilizou, em demasia, analogias entre a álgebra e a geometria. Ao indicar o quão vantajoso para ciência é o estabelecimento de relações analógicas entre fenômenos, Mach cita exemplos exitosos de descobertas no campo das ciências naturais que resultaram da utilização do método analógico ${ }^{59}$.

Em Introdução à epistemologia freudiana, Assoun examina a forte autoridade machiana sobre a plataforma epistemológica de Freud. A seção intitulada "A fonte da metapsicologia freudiana: Ernst Mach”, cumpre a tarefa de mapear a presença do físico

\footnotetext{
${ }^{56}$ FULGENCIO, O método especulativo em Freud,365. Trabalhamos essa temática com mais demora em: Ribeiro, Freud e o Methodenstreit: um debate a partir dos Seminários de Zollikon

${ }^{57}$ FULGENCIO, O método especulativo em Freud,368

${ }^{58}$ Cf.: MACH, La connaissance et l'erreur.

${ }^{59}$ Outro neokantiano que entendemos ter influenciado a epistemologia de Freud foi Hans Vaihinger. Para este, "Todo conhecimento é apercepção de algo através de algo outro. Portanto, na compreensão, uma analogia é sempre operada. E não podemos ver como compreender o ser se não for desta forma. Quem conhece o mecanismo do pensamento sabe que toda compreensão e todo conhecimento se fundam em apercepções analógicas. [...] a compreensão do mundo é totalmente impossível [...] porque todo compreender só opera por via de categorias, e estas, em última instância, não representam senão apercepções analógicas”. VAIHINGER. A filosofia do como se: sistema das ficções teóricas, práticas e religiosas da humanidade, na base de um positivismo idealista, 151-152
} 
vienense nas formulações epistemológicas de Freud. Destaca que não se trata de uma influência acidental, visto que a obra de Mach - La connaissance et l'erreur - foi avaliada como um "best seller de filosofia das ciências” já no ano de sua publicação, em $1905^{60}$. Informa-nos que, no começo do séc. XX, Mach foi considerado, entre pesquisadores de língua alemã, o maior propagador de uma corrente científica triunfante que amalgamou o encontro entre a física, a fisiologia e a neurologia. Personagens evocados por Freud como ícones de rigoroso labor científico e fontes de inspiração - como Helmholtz, Brücke, Exner - reconheciam Mach como o grande nome capaz de traduzir em epistemologia suas práticas científicas ${ }^{61}$.

Mach avalia que a física, ao postular o conceito de força, o construiu por analogia à pressão que sentimos quando nos movemos, ou seja, o autor indica que o conceito de força consiste numa projeção antropológica na natureza. Todavia, trata-se de um conceito cabal para essa ciência. Sendo assim, na perspectiva machiana, um conceito sem realidade empírica pode ser usado como uma frutífera convenção para explicar e calcular movimentos na natureza ${ }^{62}$. Como assumido leitor de Kant, Mach defende que o uso de analogias é legitimo e necessário para organizar fenômenos e resolver problemas empíricos. Para ambos, o método analógico tem função heurística.

Sabemos que o conceito de pulsão é tomado por Freud como uma convenção sem equivalência empírica, mas que tem valor positivo na explicação de processos psíquicos. Em $A$ pulsão e seus destinos, nos informa que nem mesmo a ciência mais exata começa com definições claras e definidas, o que torna legítimo e necessário o uso de conceitos que, apesar de não serem verificáveis, têm o poder de regular a explicação de fenômenos observáveis. Nesse sentido, afirma que:

O verdadeiro início da atividade científica consiste, antes, na descrição de fenômenos, que depois serão agrupados, ordenados e correlacionados. Já na descrição não se pode evitar a aplicação de determinadas ideias abstratas ao material, ideias tomadas de algum lugar, por certo não somente das novas experiências. Tais ideias - os futuros conceitos fundamentais da ciência tornam-se ainda mais indispensáveis na elaboração posterior da matéria. [...] Portanto, elas têm a rigor o caráter de convenções, embora seja o caso de dizer que não são escolhidas de modo arbitrário, mas sim determinadas por significativas relações com o material empírico, relações essas que imaginamos poder adivinhar antes mesmo que as possamos reconhecer e demonstrar. [...] O progresso do conhecimento, entretanto, não tolera nenhuma rigidez nas definições. Como nos ensina de modo brilhante o

\footnotetext{
${ }^{60}$ ASSOUN, Introdução à epistemologia freudiana, 87

${ }^{61}$ Cf.: ASSOUN, Introdução à epistemologia freudiana.

${ }^{62}$ Cf.: FULGENCIO, O método especulativo em Freud,376
} 
exemplo da física, também os "conceitos fundamentais" firmemente estabelecidos passam por constante modificação de conteúdo ${ }^{63}$.

Ao fazer essa introdução sobre o procedimento epistemológico das ciências em geral, Freud avisa ao leitor que, tal como a física, outras ciências também se servem de convenções inobserváveis que são exitosas no fornecimento de explicações para fenômenos observáveis. O pai da psicanálise, em sintonia com os preceitos kantianos e machianos para as ciências naturais, entende que é factível usar certas ideias abstratas, oriundas "de algum lugar”, para manipular o material empírico. Tais ideias são frutíferas para esse feito, apesar de não arvorarem obter estatuto de realidade e terem valor apenas heurístico ${ }^{64}$. O conceito que se presta, de modo emblemático, a esse propósito é conceito de pulsão. Para Freud, apesar obscura, tal convenção é indispensável para a sua psicologia das profundezas.

Como nos avisa o pai da psicanálise, no trecho citado, a escolha das convenções não é arbitrária e sem relação significativa com o material empírico, por isso a defesa da existência de pulsões que agem como forças motrizes no interior do aparelho psíquico buscou semelhança analógica com as forças físicas que agem sobre a matéria. Ainda que o conceito de pulsão ressinta de exatidão e não possa ser explicitado com absoluta clareza, a meta da pesquisa psicanalítica é avançar - sem tolerar qualquer rigidez - rumo a definições mais claras. Isso implica dizer que qualquer convenção, na medida em que faz parte da superestrutura especulativa da psicanálise pode “(...) ser abandonada ou modificada, sem perda ou pesar, no momento em que sua insuficiência tenha sido provada" ${ }^{65}$. Sabemos que o dualismo pulsional instituído por Freud mudou ao longo de sua obra. Na medida em que a dicotomia entre a pulsão de autoconservação e a pulsão sexual não era mais frutífera para explicar fenômenos clínicos, Freud se viu forçado a postular outro par de pulsões: a de vida e a de morte. Diante dessa mudança, cabe a pergunta: esse tipo de alteração em busca de conceitos mais próximos da realidade empírica é um recuso exclusivo da metodologia científica da psicanálise? A resposta é: não! Como o próprio pai da psicanálise afirma: “o mesmíssimo método é adotado pelas ciências mais antigas"66. Em suma, podemos afirmar que, tanto na física quanto na psicanálise, o fundamento da ciência é a observação, mas o uso de conceitos nebulosos que compõem a superestrutura especulativa (Spekulativer Überbau) pode servir, ainda que temporariamente, para organizar o material oriundo da empiria. Por não serem conceitos nitidamente definidos, as convenções

\footnotetext{
${ }^{63}$ FREUD, A pulsão e seus destinos, 15-16.

${ }^{64}$ A presença do espólio machiano na obra de Freud salta aos olhos, a ponto de Assoun advertir que, ao fazer a leitura de La connaissance et l'erreur, de Ernst Mach, o leitor familiarizado com os textos freudianos pode correr o risco de ser “(...) vítima de um verdadeiro efeito de paramnésia”. Para Assoun, o capital epistemológico da psicanálise tem sua fonte na concepção machiana de ciência, o que lhe permite indicar certo “isomorfismo entre o texto de Mach e o de Freud”. ASSOUN, Introdução à epistemologia freudiana, 87 ${ }^{65}$ FREUD, Um estudo Autobiográfico,38

${ }^{66}$ FREUD, Um estudo Autobiográfico, 38
} 
Não são a base, mas o topo de toda a estrutura, e podem ser substituídas e eliminadas sem prejudicá-la. Em nossos dias, a mesma coisa vem acontecendo na física, cujas noções básicas no tocante a matéria, centros de força, atração etc, são quase tão discutíveis quanto as noções correspondentes em psicanálise ${ }^{67}$.

Consoante a citação acima, tanto a física quanto a psicanálise recorrem a conceitos pouco definidos para manipular o material oriundo da observação. Ainda que esta ou aquela convenção possa ser descartada ou modificada, o emprego desse tipo de ferramenta é extremamente lícito e não anuncia qualquer desleixo para com a racionalidade científica. Por esse motivo, Freud reconhece que - sem especulação e teorização metapsicológica - a psicanálise não daria um passo à frente ${ }^{68}$.

O conceito de pulsão cumpre o papel de fornecer explicações acerca da formação dos sintomas e demais formações inconscientes, como os sonhos, atos falhos e chistes. Como diz Assoun, a pulsão é vista por Freud como o primum movens de todas as combinações psíquicas e, por isso mesmo, é extremamente frutífera na explicação dos fenômenos humanos ${ }^{69}$. Tal como nos alertou Heidegger, não só esse conceito, mas toda a metapsicologia freudiana tem suas raízes fincadas em solo de influência kantiana e científico-natural. De Kant e dos neokantianos, Freud legou a defesa do uso de ficções com valor heurístico e de convenções do tipo como se. Do grande porta-voz da ciência natural do começo do século XX e assumido leitor de Kant, Ernst Mach, Freud herdou, dentre outros legados, a legitimidade do uso de analogias para estabelecer relações entre fenômenos.

$\mathrm{Na}$ medida em que constrói a parte teórica de sua psicanálise - a metapsicologia num solo onde está assegurado o legado científico-natural, Freud, na ótica heideggeriana, destina ao homem modos de apreensão que são pautados numa objetividade não-humana e, por isso mesmo, são questionáveis. Afinal, o homem não é um ente natural, mas um ente que requer um tratamento cativo à seara das ciências humanas. A tentativa de explicabilidade de nossas urgências e ímpetos a partir de um conceito que se inspira, por analogia, com as forças físicas cumpre, na leitura de Heidegger, o papel de obrigar o fenômeno humano a responder a condições de objetividade não-humanas.

Indicamos que termo pulsão é, para Freud, tão obscuro quanto uma entidade mítica e nos perguntamos no início desse texto: será que um decidido cientista natural seria capaz de se referir a um aspecto de sua teoria como uma mitologia?

Vimos que o conceito de pulsão, apesar de ser assumidamente obscuro, está a serviço do desenvolvimento da pesquisa psicanalítica em consonância com parâmetros

\footnotetext{
${ }^{67}$ FREUD, Sobre o narcisismo: uma introdução, 85

${ }^{68}$ FREUD, Análise terminável e interminável, 241

${ }^{69}$ ASSOUN, Introdução à epistemologia freudiana, 211
} 
considerados legítimos pela ciência da natureza típica do fim do século XIX e do começo do século XX. Análoga às forças de atração e repulsão da física, a pulsão freudiana cumpre o papel de ser o fator motriz das ações humanas. Essa convenção denominada pulsão, ou seja, essa construção auxiliar entendida como uma força constante no interior do psiquismo, permite a Freud apontar a causa de fenômenos clínicos, noutros termos, permite a Freud explicá-los.

Apesar de entendermos que o conceito de pulsão cumpre a função de ser o motor das mobilizações psíquicas e que isso está a serviço de uma explicação causal, ainda é possível retomar, nesse momento do texto, a anunciada dificuldade em articular ciência da natureza e mitologia. O que dizer de um cientista natural que equivale seu conceito cardeal a uma entidade mítica?

Com o intuito de levar a cabo os questionamentos enunciados nesse texto, recorrermos a comentários feitos por Fulgencio no livro O método especulativo em Freud e a argumentos desenvolvidos por Ernst Mach na obra La connaissance et l'erreur. Fulgencio afirma que, para Mach, o exercício científico deve buscar a máxima correspondência entre a representação de um conjunto de fenômenos e a realidade fenomênica, entretanto, nem sempre isso é possível. Em casos como esse, o cientista deverá recorrer ao que Mach denomina de representações fantasias (Phantasie-Vorstellungen), ou seja, o cientista precisará apelar para representações auxiliares que, apesar de não terem referência empírica e de serem fantasias, podem ser úteis à organização e ao estabelecimento de relações entre os fenômenos ${ }^{70}$. Claro, nos alerta Mach, tal recurso deve ter caráter provisório, deve ser revisado constantemente para se possa, com o avançar da pesquisa, alcançar uma descrição dos fatos sem o amparo dessas fantasias. Seguindo essa mesma linha de raciocínio, Freud afirma a ciência deve tolerar o revisionismo constante e avançar sem rigidez ${ }^{71}$. Em franca sintonia com os preceitos machianos, o pai da psicanálise nos adverte que um constructo especulativo, ao se mostrar estéril na resolução de problemas, deverá ser abandonado por outro mais frutífero, até que se chegue a um estágio de evolução, no qual as representações fantasias sejam dispensáveis. Um exemplo freudiano de alteração no uso de seus constructos especulativos se refere à alteração no par antagônico das pulsões.

Em La connaissance et l'erreur, especificamente no capítulo denominado "L'exubérance des idées”, Mach nos cita exemplos oriundos da história da física que ilustram o recurso a esse tipo de fantasia teórica. O autor nos fala que a física, em suas diversas configurações históricas, sempre recorreu a uma espécie de "mitologia da

\footnotetext{
${ }^{70}$ Cf.:MACH, La connaissance et l'erreur, 112. Trabalhamos essa influência de Mach sobre a metapsicologia de Freud em: FERREIRA e RIBEIRO, A metapsicologia freudiana: uma leitura heideggeriana.

${ }^{71}$ Cf.: FREUD, Sobre o narcisismo: uma introdução, 84
} 
natureza"72. O autor esboça a história da física e indica que esta mitologia se caracterizou, inicialmente, como animista, sendo substituída, aos poucos, por uma mitologia das substâncias, seguida por uma mitologia mecânica e automática, para, finalmente, configurar-se como uma mitologia dinâmica. A evolução ocorrida na física demonstra o caráter temporário de cada elemento fantasioso ou mitológico, bem como a sua possibilidade de substituição por outro mais frutífero ${ }^{73}$. Em seu itinerário de amadurecimento e consolidação, uma ciência acaba lançando mão da utilização de recursos mitológicos. Mach faz um inventário com exemplos de uso de recursos fantasiosos ou mitológicos utilizados na química, física e geometria. Aqui nos interessa menos explanar sobre esses exemplos em outras ciências, do que apontar que o uso de mitologias por estas ciências é algo legítimo e não atenta contra a cientificidade delas.

Fulgencio nos indica que na obra original em alemão, intitulada Erkenntnis und Irrtum, designadamente no último parágrafo do capítulo VI, Mach afirma que as representações fantasias, tal como uma festa das bruxas (Hexensabbat), impõem respeito. Tal parágrafo, denuncia Fulgencio, foi mutilado na tradução francesa La connaissance et l'erreur - realizada por Marcel Dufour - e a referência às bruxas não aparece ${ }^{74}$. Veremos, em breve, quão importante para análise da metapsicologia freudiana e do conceito de pulsão é essa parte excluída na versão francesa.

Tal como exposto acima, Mach defende que na evolução histórica da relação entre mitologia e ciência, a perspectiva dinâmica é a mitologia mais desenvolvida. Mesmo que o objetivo mais elevado de uma ciência madura seja a eliminação dessas mitologias, Mach reconhece que todo o processo de evolução da física e de outras ciências teve o suporte desse tipo de recurso. Por isso, o autor no indica que devemos respeitar os aspectos mitológicos e as representações-fantasia como respeitamos as bruxas (Hexen). A advertência feita pelo autor de La connaissance et l'erreur em relação ao uso de elementos fantasiosos, consiste em manter uma diligente atenção para não confundir o que é da

\footnotetext{
${ }^{72} \mathrm{MACH}$, La connaissance et l'erreur,77

${ }^{73}$ Cf.: FULGENCIO, O método especulativo em Freud. 189. Vale trazer uma citação de E. Mach, extraída da obra A mecânica: exposição histórica e crítica de seu desenvolvimento, que esclarece a provisoriedade dos constructos especulativos: "Não é impossível que um dia as leis integrais (para empregar uma expressão de C. Neumann) substituam as leis elementares que constituem a mecânica atual e que nós possamos ter assim um conhecimento direto da dependência recíproca das posições dos corpos. Então o conceito de força terá se tornado supérfluo". MACH, 1883, p. 250, Apud: FULGENCIO, Convocação para a fundação de uma 'Sociedade para a Filosofia Positivista', 434.

${ }^{74}$ Fulgencio, em nota de rodapé, nos fala dessa mutilação na tradução francesa. O autor nos indica que o trecho utilizado por ele foi retirado do original com a tradução de Loparic. Cf.: FULGENCIO, O método especulativo em Freud.143.
} 
ordem da fantasia (da representação-fantasia), com o referente empírico que ela ajuda a ordenar.

Como já indicamos, a obra de Ernst Mach que fala de mitologia da natureza, de representação fantasia e de bruxas, foi considerada um "best seller de filosofia das ciências” no começo do século XX e influenciou grande número de cientistas de língua alemã, dentre eles, Freud. Sendo assim, avalizado por Mach quanto ao valor das mitologias, o pai da psicanálise, enquanto representante da ciência natural de seu tempo, sentiu-se confortável em recorrer à sua própria. Desse modo, assumiu, sem constrangimento, que a teoria das pulsões é a sua mitologia e, mesmo padecendo de grandiosa imprecisão, tal teoria é considerada fundamental para o desenvolvimento de sua ciência ${ }^{75}$.

No livro Introdução à Epistemologia Freudiana, Assoun afirma que o modo freudiano de conceber a prática científica repousa na pena de Ernst Mach. Freud assume em franca filiação à plataforma epistemológica da Mach - o caráter incompleto e tateante das teorizações científicas e o quanto estas devem poder receber acréscimos e modificações, evitando qualquer tipo de dogmatismo. $O$ uso de mitologias e representações-fantasias (Phantasie-Vorstellungen) não é algo que coloca sob suspeita cientificidade natural da psicanálise. Os conceitos metapsicológicos funcionam como representações-fantasias com valor heurístico, já que são frutíferos para organizar os dados oriundos da clínica. Mas, mesmo sendo um celeiro de conceitos ficcionais, a teoria metapsicológica exige respeito, tal como a festa das bruxas (Hexensabbat) exige.

Em Análise terminável e interminável, o pai da psicanálise faz uma menção a bruxas. Freud, ao versar sobre o sucesso ou fracasso do tratamento analítico, expõe suas teorias sobre o conflito pulsional e os efeitos destes na personalidade. Num determinado momento do texto afirma que se fosse perguntado por quais métodos alcança os resultados de sua teoria, seria forçado admitir o quão difícil é achar uma resposta. Poderia apenas responder: "Só há um meio então: é à bruxa recorrer!”76.

\footnotetext{
${ }^{75}$ Numa carta a Einstein em que levantou a pergunta "Por que a guerra?", Freud utiliza o conceito de pulsão de morte para explicar o componente destrutivo do homem que o faz aderir ao combate. Em seguida pondera: "Talvez ao senhor possa parecer serem nossas teorias uma espécie de mitologia e, no caso presente, uma mitologia nada agradável. Todas as ciências, porém, não chegam ao final a espécie de mitologia como esta? Não se pode dizer o mesmo, atualmente, a respeito de sua na física?”. FREUD, Por que a guerra? 204. Esse questionamento não apresenta qualquer espécie de deselegância em relação ao físico, afinal, os dois faziam parte de uma "Sociedade de Filosofia Positivista" - juntamente com Max Planck, David Hilbert e Félix Klein e compactuavam perspectivas epistemológicas neokantianas. Cf.: FULGENCIO, Convocação para a fundação de uma 'Sociedade para a Filosofia Positivista', 430

${ }^{76}$ FREUD, Análise terminável e interminável, 241. Discutimos essa temática em BARBOSA e RIBEIRO, $O$ conceito de pulsão na psicanálise freudiana: considerações à luz da filosofia da Martin Heidegger
} 
Uma nota de rodapé indica que essa citação foi retirada da obra Fausto, de Goethe. A passagem mencionada por Freud é retirada da cena cujo cenário é descrito por Goethe como uma espécie de cozinha na qual se encontra um fogão aceso com uma grande panela que contém um caldo em fervura, exalando vapores, e as paredes estão adornadas com estranhos utensílios de feitiçaria. Fausto, diante desse bizarro local, fala a Mefistófeles: “A mim inspira horror toda feitiçaria; Prometes que acharei, alguma melhoria; nesse sujo covil de estranhos objetos?”. Em tom de desconfiança, prossegue: “Tal conjunto de troços, imundos, abjetos; Remoçará meu ser trinta anos, se quiser?"77. Mefistófeles, percebendo a repugnância de Fausto em relação ao lugar, lhe diz que "há um meio natural de ser novo e formoso", mas ele requer um trabalho duro de cultivo da terra, nutrição com alimentos não condimentados, enfim, uma vida rude e reta! Fausto confessa que não poderá se adaptar a uma vida tão regrada, com enxadas a lhe cansar. Sendo assim, Mefistófeles conclui: "Só há um meio então: é à bruxa recorrer!”78.

Seduzido pela possibilidade de adquirir um bálsamo que lhe traga juventude e bonança, Fausto, a contragosto, aceita que se requisite a bruxa, a feiticeira. Para Assoun, Freud também recorre a uma feiticeira, a um oráculo que ele o batizou de metapsicologia ${ }^{79}$. Assim como o personagem de Goethe, podemos dizer que Freud preferiria prescindir de qualquer tipo de bruxaria, ou seja, de representações-fantasias (Phantasie-Vorstellungen), por isso, muitas vezes, se lamenta de ter que lançar mão de conceitos metapsicológicos que são obscuros e nebulosos, todavia, mesmo diante da pouca claridade de sua metapsicologia, não pode eximir-se de adotá-la como elemento cardeal para a condução de seus passos científicos. Isso se constata na assertiva: "Sem especulação e teorização metapsicológica quase disse fantasiar - não daremos outro passo à frente. Infelizmente, aqui como alhures, o que a bruxa (Hexe) nos revela não é muito claro, nem muito minucioso" ${ }^{80}$.

Mesmo contrariado, o culto e pretensioso Fausto, cede e toma o "elixir" da bruxa. De modo análogo, podemos dizer que Freud - ainda que ressentido pela pouca clareza e pela falta de minúcia dos conceitos metapsicológicos - é "seduzido" pela "bonança” metodológica do "elixir" da metapsicologia. Se a sua psicologia das profundezas pudesse prescindir de especulações, certamente o faria. Mas não pode, restando-lhe apenas: à bruxa recorrer! Para isso, o pai da psicanálise conta com o aval do próprio E. Mach, visto que o físico afirma que as representações-fantasias não podem ser desprezadas e devem ser apreciadas com a deferência que uma festa das bruxas (Hexensabbat) impõe. Sob a tutela de Mach, Freud se serve do termo mitologia e de sua função epistêmica não para se

\footnotetext{
77 GOETHE, Fausto, 116

${ }^{78}$ GOETHE, Fausto, 117

${ }^{79}$ Cf.: ASSOUN, Introdução à epistemologia freudiana, 103

${ }^{80}$ FREUD, Análise terminável e interminável, 241
} 
desenraizar do solo científico-natural, mas para firmar-se nele. E, fincado nesse solo, postula a presença de um jogo de forças pulsionais no interior do aparelho psíquico servindo-se não só da semântica das ciências da natureza, mas de seu modo de pensar o fazer científico. É nesse sentido que caminha a crítica de Heidegger à herança científiconatural e neokantiana presente na metapsicologia e, consequentemente, no conceito de pulsão.

\section{Hermenêutica ou ciência natural? O conceito de pulsão e a identidade epistêmica da psicanálise}

Em nossa tentativa de conclusão, pleiteamos responder à inquietação ventilada já no início do artigo, tal inquietação refere-se ao fato de Freud assumir que a pulsão é uma "entidade mítica". A suspeita que sustentamos no decorrer desse trabalho diz respeito ao fato de pressupormos que os termos "mitologia" e "ciência" pudessem ser antípodas e repulsantes. Foi essa suspeita que nos fez ponderar se realmente poderíamos aceitar a tese heideggeriana de que a psicanálise seria uma ciência da natureza e de que o conceito de pulsão estaria a serviço de uma objetividade não-humana. Pois bem, diante do que foi exposto, podemos dizer que a opacidade de um conceito, sua aura mitológica e pouco definida, não é um entrave para a pesquisa no campo das coisas naturais, ao invés, a utilização de ficções ou especulações é lícita e preconizada pelo eminente físico Ernst Mach. Desse modo, a assunção freudiana da nebulosidade do conceito de pulsão e sua definição como uma "entidade mítica” não é algo que abala a credibilidade de seu saber e arranca-lhe a insígnia de ciência natural; ao contrário, é algo avalizado pela ciência de seu tempo, tal como é avalizada a admissão de que o conceito de força, na física, é uma construção especulativa, é uma construção oriunda da etapa mais moderna da "mitologia da natureza”, a etapa dinâmica.

Para Ricoeur, ao qualificar a teoria das pulsões como sua mitologia, Freud estaria acentuando esse aspecto mitológico como algo irredutível ao naturalismo. Após a análise da epistemologia de Mach, nos parece claro que o uso do termo mitologia não entra em choque com os preceitos das ciências da natureza. Sendo assim, para finalizar nosso texto, convém lembrar que, não obstante a profundidade da argumentação de Ricoeur sobre o possível elo entre força e sentido contido no constructo pulsão, somos levamos a entender que o mapeamento da herança presente na obra de Freud torna evidente que suas raízes não podem ser arrancadas do solo naturalista sob pena de se negligenciar ou até mesmo se recusar um profundo diagnóstico histórico do processo de construção da plataforma epistemológica da psicanálise. Em nossa leitura, consideremos difícil entender Freud como um combatente da hermenêutica, tal como quer Ricoeur. 
Assoun nos assegura que, ao ler a tão documentada e argumentada obra de Ricoeur, teve a impressão de que a hermenêutica se debruçou no berço do freudismo para livrá-lo de sua origem deplorável - de verve naturalista e energetista ${ }^{81}$. Segundo o autor em comento, a estratégia de Ricoeur em relação ao itinerário da pesquisa psicanalítica nos lembra a narrativa de Diotima para a gênese de Eros, proferida no diálogo $O$ banquete.

Diotima narra que Eros foi gestado na festa de aniversário de Afrodite, quando um dos convivas do banquete, Poros (o astuto, o engenhoso), embriagado de néctar deitou-se com aquela que estava à porta buscando restos, Penúria (a mendicante). A característica da concepção do deus do amor marcaria a sua natureza, à qual seria conferida tanto o vigor e a engenhosidade herdada do pai, quanto a indigência e a carência oriundas da mãe, daquela que é locatária da miséria e da desventura. Sendo assim, sentencia a estrangeira de Mantineia sobre Eros: "Filho de Penúria e Poros, a origem determinou-lhe a sorte"

Assoun entende que, tal como o Eros contado por Diotima, a psicanálise - segundo Ricoeur - teria uma nobreza por parte de pai (a hermenêutica), mas padeceria da indigência materna (a energética). Para o comentador, Ricoeur tenta superar essa duplicidade constitutiva da psicanálise "pelas virtudes salvíficas" de uma nova hermenêutica ${ }^{83}$. Assoun lança suspeita sobre o êxito dessa tarefa. Em contrapartida ao empenho de Ricoeur, retomamos as palavras de Diotima: a origem é que determina a sorte! O que implica dizer que não dá para se desembaraçar, tão facilmente, do naturalismo constitutivo do começo e presente também em escritos tardios, como nos textos metapsicológicos e, como vimos, até mesmo no conceito de pulsão.

A partir da indicação heideggeriana sobre a presença do kantismo e da metodologia científico-natural na metapsicologia, pudemos perceber que o uso de ficções e analogias é afiançado pelo modo como se concebe a ciência no tempo de Freud. Sendo assim, cumpre reconhecer que o uso constante de analogias para descrever o aparelho psíquico, a energia sexual (libido), o jogo de oposição pulsional, não representa, como assevera Fulgencio, um recurso literário ou um traço de estilo do texto freudiano, mas uma assumida posição metodológica afiançada pelo pensamento neokantiano e pela epistemologia de $\mathrm{Mach}^{84}$. O que nos faculta afirmar que, se Freud se esforçou, incansavelmente, em inscrever a sua psicanálise na lista das ciências naturais de seu tempo, o uso de especulações não minou esse esforço, apenas o auxiliou. E o conceito de pulsão e o dualismo pulsional lhe serviram como um subsídio frutífero para o alcance dessa meta.

Vimos que o ponto de vista de Ricoeur em relação ao conceito de pulsão, consiste em defender que tal conceito teria o poder de arrancar a psicanálise do cientificismo natural

\footnotetext{
${ }^{81}$ ASSOUN, Introdução à epistemologia freudiana, 35

${ }^{82}$ PLATÃO, O Banquete 95

${ }^{83}$ ASSOUN, Introdução à epistemologia freudiana, 35

${ }^{84}$ Cf.:FULGENCIO, O método especulativo em Freud, 355
} 
típico de seus primórdios e aproximá-la de uma hermenêutica. Vimos, também, que o conceito de presentação da pulsão fez com que Ricoeur advogasse pela supremacia do campo de sentidos. Por isso, Ricoeur afirma que a psicanálise jamais põe em confronto forças nuas, mas sempre forças em busca de um sentido. Ricoeur argumenta que o destino energético das pulsões só aparece enquanto destino de suas expressões psíquicas, o que tornaria este conceito o responsável pela subordinação dos aspectos energéticosnaturalistas ao campo de sentido. Daí decorreria a sua força para arrancar a psicanálise do solo científico-natural do começo do itinerário freudiano

Heidegger, por sua vez, indicou o solo sobre o qual se ergueu a psicanálise e mostrou sua sintonia com uma herança proveniente da ciência e da filosofia de matriz neokantiana. O filósofo nos desvelou o quanto Freud se serve de uma objetividade não-humana para falar do homem. Transitando na clareira aberta pelos questionamentos heideggerianos, podemos perceber que o fato de Freud ter em mãos um conceito nebuloso como o de pulsão não revela uma ruptura como o modelo de ciência natural vigente em seu tempo, ao invés, faz coro a este modelo. A argumentação que indica que uma ciência que se serve de conceitos pouco definidos e especulações não pode ser confortavelmente alocada no rol das ciências da natureza, não considera a epistemologia de Mach e a presença de Kant como um patrono de uma concepção de ciência que legitima o uso de ficções heurísticas. Vimos que até mesmo as ciências mais duras, na perspectiva machiana, servem-se de mitologias, de representações-fantasias e as respeitam como se deve respeitar uma festa das bruxas (Hexensabbat). Sendo assim, o sentido de "mitologia" não teria relação com um saber antípoda do fazer científico-natural, mas teria o sentido que Mach lhe empresta. Ao considerarmos tudo isso, nos sentimos compelidos a concordar com a argumentação instituída por Heidegger e iluminada por Assoun, Loparic e Fulgencio: Freud é um arauto das ciências da natureza de seu tempo e o conceito de pulsão é uma grande ferramenta na consolidação dessa identidade epistêmica.

\section{Referências}

ALMEIDA, F. J. ; RIBEIRO, C. V. Freud e a teoria da elaboração dos sonhos: investigações à luz da filosofia de Martin Heidegger e de Paul Ricoeur. Revista Ideação, Edição Especial, n. 1, p. 181-218, 2018

ASSUON, P. L. Introdução à epistemologia freudiana. Rio de Janeiro: Imago, 1983

BARBOSA, J. J. ; RIBEIRO, C. V.O conceito de pulsão na psicanálise freudiana: considerações à luz da filosofia da Martin Heidegger. Revista Ideação, Edição Especial, n.1, p. 474-509, 2018. 
FRANCO, S. Hermenêutica e psicanálise na obra de Paul Ricoeur. São Paulo: Edições Loyola, 1997

FREUD, S. As pulsões e seus destinos. Tradução Pedro Heliodoro Tavares. Edição Bilingue. Belo Horizonte: Autêntica, 2013.

FREUD, S. Ansiedade e vida pulsional. Novas Conferências Introdutórias sobre a Psicanálise; Conferência XXXII. in: FREUD, S, Edição Standard brasileira das obras completas de Sigmund Freud. Rio de Janeiro: Imago Editora, 1996a. Vol. XXII

FREUD, S. O inconsciente. In: FREUD, S, Edição Standard brasileira das obras completas de Sigmund Freud. Rio de Janeiro: Imago Editora, 1996b. Vol. XIV

FREUD, S. Repressão. in: FREUD, S, Edição Standard brasileira das obras completas de Sigmund Freud. Rio de Janeiro: Imago Editora, 1996c. Vol. XIV

FREUD, S. Um estudo Autobiográfico. in: FREUD, S, Edição Standard brasileira das obras completas de Sigmund Freud. Rio de Janeiro: Imago Editora, 1996d, Vol. XX.

FREUD, S. Sobre o narcisismo: uma introdução. in: FREUD, S, Edição Standard brasileira das obras completas de Sigmund Freud. Rio de Janeiro: Imago Editora, 1996e, Vol. XIV.

FREUD, S. Por que a guerra? in: FREUD, S, Edição Standard brasileira das obras completas de Sigmund Freud. Rio de Janeiro: Imago Editora, 1996f. Vol. XXII.

FREUD, S. Análise terminável e interminável. in: FREUD, S, Edição Standard brasileira das obras completas de Sigmund Freud. Rio de Janeiro: Imago Editora, 1996g. Vol. XXIII

FULGENCIO, L. Convocação para a fundação de uma 'Sociedade para a Filosofia Positivista. Natureza Humana - Revista Internacional de Filosofia e Psicanálise. São Paulo: EDUC, 2000, vol.2, n.2

FULGENCIO, L. O método especulativo em Freud. São Paulo: EDUC, 2008

GARCIA-ROZA, L. Introdução à metapsicologia freudiana, v.3. Artigos de metapsicologia: narcisismo, pulsão, recalque, inconsciente. $7^{\text {a }}$ ed. Rio de Janeiro: Jorge Zahar Ed., 1995

GOETHE, J. W. Fausto - poema dramático. Tradução, notas e posfácio de Silvio Meira. São Paulo: Abril Cultural, 1976

HANNS, L. Dicionário comentado do alemão de Freud. Rio de janeiro: Imago Editora, 1996. HEIDEGGER, M. Seminários de Zollikon. Tradução de Gabriella Arnhold e Maria de Fátima de Almeida Prado. São Paulo: EDUC, 2001

KANT, I. Princípios metafísicos da Ciência da Natureza. Tradução Arthur Mourão. Lisboa, Edições 70. 1990 
LAPLANCHE, J. E PONTAlis, J.B. Vocabulário da Psicanálise. Tradução: Pedro Tamen. São Paulo: Martins Fontes, 2008.

LOPARIC, Z. Além do Inconsciente - sobre a desconstrução heideggeriana da psicanálise. Natureza Humana - Revista Internacional de Filosofia e Psicanálise. São Paulo: EDUC, vol. 3.n 1,2001

LOPARIC, Z. A semântica transcendental de Kant. Campinas: CLE, 2002.

LOPARIC, Z. As duas metafísicas de Kant. Kant e-prints, vol 2, n 5. 2003.

LOPARIC, Z. A máquina no Homem in: FULGENCIO, L. e SIMANKE, R. (org). Freud na Filosofia Brasileira. São Paulo: Escuta, 2005

MACH, E. La connaissance et l'erreur. Traduction: Marcel Dufour. Paris: Ernest Flammarion, 1919.

MONZANI, L, R. Freud: o movimento de um pensamento. Campinas: Editora Unicamp, 1989.

PLATÃO. O Banquete. Tradução, notas e comentários de Donald Schüler. Porto Alegre: L\&PM, 2009

VAIHINGER, H. A filosofia do como se: sistema das ficções teóricas, práticas e religiosas da humanidade, na base de um positivismo idealista. Tradução de Johannes Kretschmer. 1 ed. Chapecó: Argos, 2011.

RIBEIRO, C. V. Freud se encaixaria no rol dos operários (Handwerker) das ciências naturais? Considerações heideggerianas acerca da psicanálise freudiana. Aprender: Caderno de Filosofia e Psicologia da Educação. Vitória da Conquista: Edições UESB, v. 10, 2008.

RIBEIRO, C. V. Freud e o Methodenstreit: um debate a partir dos 'Seminários de Zollikon'. Diálogos Possíveis (FSBA), v. 13, p. 97-123, 2014.

RICOEUR, P. Da interpretação: ensaio sobre Freud. Rio de janeiro: Imago Editora, 1977. RICOEUR, P. O conflito das interpretações: ensaios de hermenêutica. Rio de Janeiro: Imago editora, 1978 